V.V.Sobolev ${ }^{1}$, Dr. Sc. (Tech.), Prof., orcid.org/0000-0003-1351-6674,

V.V.Kulivar ${ }^{1}$, orcid.org/0000-0002-7817-9878, O. L. Kyrychenko ${ }^{2}$, Cand. Sc. (Tech.), orcid.org/0000-0002-1331-9323,

A. V. Kurliak ${ }^{2}$, orcid.org/0000-0001-8704-3414, O. O. Balakin ${ }^{2}$, orcid.org/0000-0003-2003-0381

\title{
EVALUATION OF BLAST WAVE PARAMETERS WITHIN THE NEAR-EXPLOSION ZONE IN THE PROCESS OF ROCK BREAKING WITH BOREHOLE CHARGES
}

Purpose. To analyse the experimental results, to describe physical mechanism of blasted rock disintegration and develop methodology to calculate blast-wave parameters within the near-explosion zone, and to study possible role of thermoelastic stresses in rock fragmentation to ultradisperse fractions in the near-explosion zone.

Methodology. The experiments involved a method to measure dynamic compressibility of bituminous coals based on the determination of both velocity of blast waves and mass velocity of particles beyond the front. A reflection method is used to construct isentropes of the explosive detonation products and their impact adiabat.

Findings. Experimental studies are carried out to analyse compressibility parameters of bituminous coals - blast wave velocity and mass velocity of particles beyond the blast wave front. Impact adiabats for emulsion explosive EPA P-3 and bituminous coals are constructed. A set of theoretical studies is performed.

Originality. Methodology to evaluate blast-wave parameters within the zone near the borehole or blasthole charge explosion is proposed. Physical mechanism for rock breaking to ultradisperse particles is proposed. It has been specified that thermoelastic stresses may be one of the possible causes, if not the main one, of the rock breaking within the near-explosion zone. A mechanism stipulated by the transition of microstructure of the rock crystalline components to the instable state is considered as the alternative (or additional) factor. The cause is in the oversaturation of the rock microstructure with the linear and point defects. Exceeded value of critical concentration of those defects results in the excessive reserves of internal energy with the following spontaneous breaking of chemical bonds. Impact adiabats of coking coals of three grades as well as isentrope and impact adiabat of the detonation products of emulsion explosive EPA P-3 are constructed. In terms of the "pressure - mass velocity of particles" coordinates, curves of adiabats of the bituminous coals differ by not more than $4 \%$.

Practical value. Analysis of the scientific results may be the required condition to develop additional safety measures in the sphere of environmental protection during blasting operations in terms of open-pit and underground mining.

Keywords: explosion, rock, impact adiabat, isentrope of explosion products, thermoelastic stresses

Introduction. Rock breaking by blasting affects considerably the economic expediency and technological efficiency of further operations: excavation of the rock mass, its transportation, dressing, processing and others. Thus, the main objective of blasting rock breaking while mining is to obtain the specified granulometric composition [1, 2]. Breaking of rock within the charge-adjacent zone to the micron-range particles and even to the nanoscale sizes is one of the negative results of blasting of the borehole and blasthole charges [3]. Compared to the microparticles, particles of the nanoscale class turn to be more aggressive in terms of their effect on human organisms [4]; generally, that problem belongs to the priority tasks of the labour protection as a complex of technical, biomedical sciences, and some others. Newly formed particles with a chemically active surface characterized by certain value of the distribution of electric charge density are especially hazardous [5]. Apart from biomedical, social, technical, and environmental problems, excessive mineral fragmentation results in overall economic damage stipulated among other things by considerable losses of mineral raw materials [6], e.g. as a result of largescale blasts during non-metallic open-pit mining [7,8].

Analysis of the environmental situation in the atmosphere of mining and industrial regions shows that the potential of current models for atmospheric air control is almost exhausted [9]. Such a negative phenomenon as excessive rock fragmentation during blasting rock breaking requires development of new models and active search for innovative engineering solutions.

(C) Sobolev V.V., Kulivar V.V., Kyrychenko O. L., Kurliak A. V., Balakin O. O., 2020
The main problem is in the "negative" effects which are inevitable within the explosive - rock (E-R) interface. Based on that fact, there is an opinion that E- $\mathrm{R}$ interface will always demonstrate the excessive rock fragmentation; in this context, fragmentation volume and degree will depend on both its physicomechanical properties and blasting characteristics of the explosive. It becomes quite obvious that in terms of the known rock characteristics, selection of the explosive [6] makes it possible to calculate rational blasting pattern and provide minimal losses of mineral raw material. However, selection of the explosive with decreased brisance may be the cause of the increasing oversize material output [10]. To solve the problem partially, different designs of blasthole charges were proposed: with the dispersed air gaps [11, 12] and with the gaps between the charging chamber walls and explosive charge [13, 14] filled with the inert material.

Paper [6] carries out comparative analysis of the blasting action from the powder charges to the brisant explosives; different mechanisms of rock breaking within the near zone in terms of the immediate contact of the explosive with the charging chamber walls. The results obtained by the authors [6] express regular connection of the qualitative indices while blasting in terms of the models. It is possible to use the author's conclusions as the approved tendency in case of blasting of real boreholes. Taking into consideration excessive rock fragmentation, fraction mismatch in terms of the lower loss limit may be from 8.5 to $45 \%$ at non-metallic mining enterprises. In this context, according to the estimations of different authors, radius of the zone where rock is fragmented to the unconditioned fractions may be from 1.5 to 12 radii of the explosive charge. 
The authors of paper [15] believe that there is no excessive rock fragmentation, if there is no immediate contact with the explosive charge in case of pressure of the blasting products on the charging chamber walls. That suggested mechanism may be characteristic when explosion products affect the plastic and elastoplastic rocks. In terms of such elastoplastic rock as coal, application of even flameless substances (Aerodox) results in the formation of a great number of fine fractions.

Results of the analysis of rock breaking within the near zone taking into account rock properties, explosive charge design, and physicomathematical and explosive properties of the charge are not always enough to select one or another rock breaking scenario. Estimation of impact wave parameters within the E-R interface taking into account elimination of the E-R contact may be used as the additional and required factor for correct understanding of the breaking mechanism. Such an approach makes it possible to reduce brisant action of the explosive and introduce new controllable parameter - gap between the explosive and rock made from any nonexplosive substance being in any aggregate state. Efficiency of that approach is proved by practical cases [13].

Thus, studies on the rock breaking mechanisms and development of the methods to control them are among the main tasks of the science dealing with the rock breaking by blasting.

Objective of the research is to analyse experimental results, to describe physical mechanism of rock fragmentation after blasting, and to develop a method for calculation of blast wave parameters within the near-explosion zone as well as to study possible role of thermoelastic stresses in rock breaking to the ultradisperse fractions.

Working hypotheses, assumptions. It is assumed that thermoelastic stress plays the main role in rock breaking to the ultradisperse fractions within the near-explosion zone. Role of the plasticity phase of the rock is in the fact that the plasticity "removes" the thermoelastic stresses. Development of thermal stresses is possible only in terms of the rock cooling when it is already in the elastic state. In the latter case, thermoelastic stresses become tensile ones, which reduces the threshold of the blast wave pressure resulting in the thermal breaking. Those assumptions make it possible to consider that thermoelastic stresses are one of the possible, if not the main, mechanisms of rock breaking within the near-explosion zone.

Radius of rock fragmentation during blasting may be determined using experimental dependences of stress changes in the rock mass [17]. However, that approach appears to be rather time-consuming as it is based on the experimental data which do not take into consideration physical processes, occurring during rock breaking, and parameters of stress waves within the zone of formation of finely-dispersed fractions.

Rock breaking within the near-explosion zone will continue up to the moment when the pressure in the blast wave front will not be less than the maximum stress value at which rock breaking takes place. Blast wave experiences its attenuation as a result of energy dissipation in the rock; that process is especially intense in the fractured rock mass. According to different researchers [6], radius of the zone of excessively fragmented rock is from 1.0 to 5.0 and more of the radii of the borehole explosive charge.

Increasing radius of the charging chamber (borehole) is the result of the action of expanding explosive gases and blast wave passing in the rock. Rock of the chamber walls is subject to intense heating and complex deformation - pressure with shearing. Under such conditions, microstructure of the rock-forming minerals gains maximum concentration of defects which may tell about considerable reserves of the internal energy as in case of the formation of solid bodies [17, 18]. Vacancies and dislocations are the main defects which may be responsible for energy accumulation by the crystal microstructure. Energy accumulated by the crystalline lattice at the expense of vacancy formations is many times less than the energy accumulated by dislocations [19]. M. P. Volarovich and his colleagues (1953) were the first to identify experimentally the release of internal energy reserves ac- cumulated at the expense of pressure action with shearing; they found that "blasting" rock breaking took place during the treatment of rock samples (sample thickness was $0.1-0.2 \mathrm{~cm}$, sample diameter was $0.1-0.2 \mathrm{~cm}$ ) of different genesis and different mineralogical composition. Minimal pressure value at which the breaking takes place depends on the amount of elastic energy accumulated by the rock. In his papers, M. P. Volarovich stresses that the accumulated elastic energy depends mainly on the plastic properties of the rock. In particular, in terms of marble, maximum compression pressure is more than $3 \cdot 10^{9} \mathrm{~Pa}$ being by 3-7 times higher than the minimal pressure for bituminous coals of different grades. Similar results were obtained by N.C. Yenikolopov and his colleagues during their experiments on the treatment of ionic crystals, polymer and other materials with the unidirectional pressure with shearing deformation. The phenomenon observed by the experiment authors showed that irrespective of the material, all the tested samples were broken in the way similar to the blasting-mechanism model.

Formation of lumps in the next zone, being about 10 and more of the charge radii, is explained by the mechanics in terms of standard approach to breaking, i. e. tensor of elastic stresses is calculated, and one of the known failure criteria is applied. Rock breaking within the zone of radial fractures has its satisfactory theoretical explanation. However, there is no such theoretical clarity for the case of the near-zone breaking. Virtually, reference to the fact that pressure exceeds the tensile strength does not explain anything as the continuous solid body is not broken under the effect of omnidirectional hydrostatic pressure of any value. Proper explanation of the rock breaking mechanism within the near-explosion zone should also clarify why there is no powder formation in case of explosive compression of the metal even if the pressure is by many times higher than its tensile strength.

Thus, one of the possible causes of excessive rock fragmentation within the near-explosion zone is in the thermoelastic stresses arising after the passing of intense blast wave [3, 16]. In this case, breaking scenario within the near-explosion zone is as follows. After detonation of the explosive charge into the surrounding rock, there is the propagation of the intense blast wave. After that blast wave passing, the rock remains heated up to the considerable temperature being the result of irreversible, up to $70 \%$, losses of the blast wave energy [20]. Increased temperature causes thermoelastic stresses provoking rock breaking by the type of successive scaling of layers beginning from the free surface.

Along with the distancing from the explosive, heating temperature decreases, and, beginning from certain distance, thermoelastic forces cannot cause rock breaking anymore. Everything that happens to the rock in such a concept is clearly divided into two successive processes: first - heating by a blast wave, second - breaking by the thermoelastic stresses. Both phenomena are well known separately; each of them has its own theoretical model making it possible to consider them in the totality [3]. Consequently, zone of the action of thermoelastic stresses, being capable of excessive rock fragmenting, will be limited by certain stress range beginning from the maximum value within the "explosive product - rock" interface up to some minimal value at which excessive rock fragmentation is still possible. In terms of each rock, radius of excessive fragmentation zone corresponding to the minimal stress value will have its well-defined value. Within the framework of rough approximations, it is possible to suppose that the radius of excessive fragmentation zone is comparable to the distance at which mass velocity of particles beyond the blast wave front tends to zero.

Materials and methods of research. The research involves such rock samples as: sandstone, quartz, dolomite, limestone, bituminous coals - gas coal with carbon content of $86.3 \%$ and volatile matters of $31.7 \%$, coking coal with carbon content of $88 \%$ and volatile matter of about $21 \%$. The following samples have been selected at the open pits of Ukraine: sandstone (Budanivske deposit, Ternopil oblast), dolomite (Skhidnyi dolomite open pit, Donetsk oblast), limestone (Horodnytsia open pit, Ternopil oblast), and granite (Tokovske deposit, Dniprop- 
etrovsk oblast). Blast wave parameters obtained in [21] have been applied for the quartz samples.

Blast wave parameters of the rock samples were identified by defining the equation of state based on the impact adiabat for each rock sample under analysis. Experimental studies were carried out involving methodologies represented in [21, 22]. The impact adiabat of quartz was taken from [23]. Experimental determination of linear dependence (1) for gas and cocking coals, curves of deceleration of detonation products of emulsion explosive EPA P-3 and safety emulsion explosives for coal mines were obtained according to the methodologies given in $[21,22]$. Moreover, detonation and impact adiabats of the products of emulsion explosive EPA P-3 and experimental samples of safety explosives of class IV were identified (Table 1). Emulsion explosive EPA P-3 is used for blasting operations at nonmetallic open pits; safety explosive is applied for blasting operations in coal mines dangerous in gas and coal dust explosion.

Impact adiabat is convenient to express as linear dependence [21]

$$
D_{b w}=S+b u,
$$

where $D_{b w}$ is blast wave velocity; $S$ and $b$ are coefficients; $u$ is mass velocity of the medium particles beyond the blast wave front.

Since acoustic impedance of rock $\rho_{p} S_{p}$ exceeds acoustic impedance of explosive products $\rho_{e p} S_{e p}$ for the rocks under study, blast waves will propagate in the rock and explosive products when the blast wave front goes the rock-explosive interface. In Fig. 1, pressure and velocity beyond the front of both $P^{*}$ and $u^{*}$ waves are on the intersection of the impact adiabat of the rock $(\mathrm{OD})$, Fig. 2, and detonation products (AC).

The experiments have involved a method of measurement of dynamic impact compression of bituminous coals based on the determination of the velocities of a blast wave and mass velocities of particles beyond the front [21, 22]. A method of reflection has been used to draw an isentrope of the explosive detonation products [22].

To determine $P^{*}$ and $u^{*}$, analytical calculations were performed with the use of the following expressions [21-23]

$$
\begin{gathered}
\rho_{D}\left(D_{1}-u_{D}\right)=\rho^{*}\left(D_{1}-\mathrm{u}^{*}\right) ; \\
P^{*}-P_{D}=\rho_{D}\left(D_{1}-u_{D}\right)\left(u_{D}-u^{*}\right) ; \\
\rho_{1} D_{2}=\rho^{* *}\left(D_{2}-u^{*}\right) ; \\
P=\rho_{1} D_{2} u^{*} ; \\
P^{*}=\rho_{1}\left(a+b u^{*}\right) u^{*} ; \\
P^{*}=A \rho^{*} k,
\end{gathered}
$$

where, according to Fig. 1 as well, I is state beyond the front of detonation wave with pressure $P_{D}$, density $\rho_{D}$, and mass velocity of particles beyond the wave front $u_{D}$; II is state in plane wave beyond the front of the wave reflected from the rock surface (interface) with the corresponding pressure values $P^{*}$, mass veloc-

\begin{tabular}{|c|c|c|c|c|}
\hline \multirow[b]{2}{*}{ Explosive } & \multicolumn{4}{|c|}{ Parameters } \\
\hline & 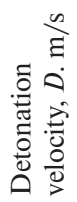 & 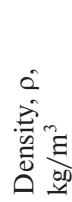 & 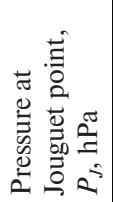 & 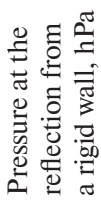 \\
\hline Explosive EPA-P-3 & 4175 & 1120 & 5.03 & 11.8 \\
\hline Safety explosive of class IV & 3861 & 1050 & 4.94 & 10.4 \\
\hline
\end{tabular}
ity of particles beyond blast wave $u^{*}$ and density of the environment beyond the blast wave propagating from the interface $\rho^{*}$; III is state in the rock beyond the blast wave front corresponding to pressure $P^{*}$, mass velocity of particles $u^{*}$, and density $\rho^{* *}$;

Table 1

Explosive characteristics of some explosives

$$
\begin{aligned}
& \text { direction of the } \\
& \text { displacement of detonation }
\end{aligned}
$$

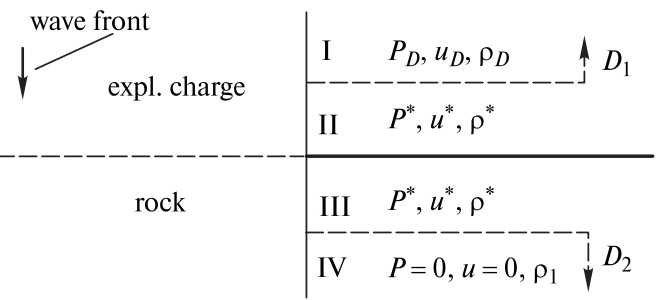

Fig. 1. Plane waves in the explosive-rock system (contact explosion) [22]:

$D_{1}$ and $D_{2}$ are velocities of blast wave and plane wave in the rock respectively

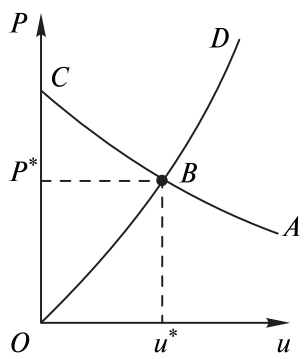

Fig. 2. General view of $P-u$ diagram [22]

IV is initial rock state corresponding to the initial parameters (pressure $P$, mass velocity of particles $u$ and density $\rho_{1}$ ).

Results. Intersection points of the impact adiabat of rock with isentrope of the explosive detonation products (explosive EPA P-3, safety explosive of class IV) correspond to the initial pressure in the rock within the explosive-rock interface.

All the evaluations were performed for the conditions of normal fall of the detonation wave front on the explosion chamber walls. According to the experiment results within the $D-u$ coordinates, impact adiabats of coals (gas and coking ones) have insignificant deviations (up to $54 \%$ ) from certain averaged curve 1 shown in Fig. 3. Thus, approximate estimation of the pressure within the explosive-bituminous coal interface requires knowing just a pressure value at the ChapmanJouguet point (Fig. 3) and $D-u$ diagrams of the rock states (Fig. 4). Area of pressures at which blast wave parameters were analysed, was not more than $30 \mathrm{hPa}$.

Fig. 3 demonstrates impact adiabats of emulsion explosives ( 1 - EPA P-3; 2 - safety explosive of class IV), P-u diagrams of rocks ( 3 - averaged adiabat for gas and coking coals; 4 - quarts; 5 - sandstone; 6 - dolomite; 7 - limestone). Intersection points of curves 2 and 3,1 and 3 correspond to the parameters and impact compressions within the explosivecoal interface. Intersection point of curves 1 and 3 coincides with the Chapman-Jouguet point of emulsion explosive EPA P-3. Since impact adiabats of the analysed coals practically coincide, generally, pressure evaluations within the explosioncoal interface may be considered as correct. Fig. 4 represents the results of studying blast wave velocity as a linear function of mass velocity of particles beyond its front.

To define threshold pressure, at which thermoelastic rock breaking takes place, use the methodology proposed in [3, 16]. If condition $V / V_{0} \approx 1$ is met (where $V_{0}$ and $V$ are specific initial volume and specific volume after compression respectively) at which compression is neglected, determine heating temperature

$$
T=\frac{(n+1) V_{0}^{2} p^{3}}{12 S^{6} c},
$$

where $n$ is constant; for solid bodies ( $n=4$ is considered to be good approximation ); $p$ is blast wave pressure; $S$ is sound velocity; $c$ is specific heat capacity. 


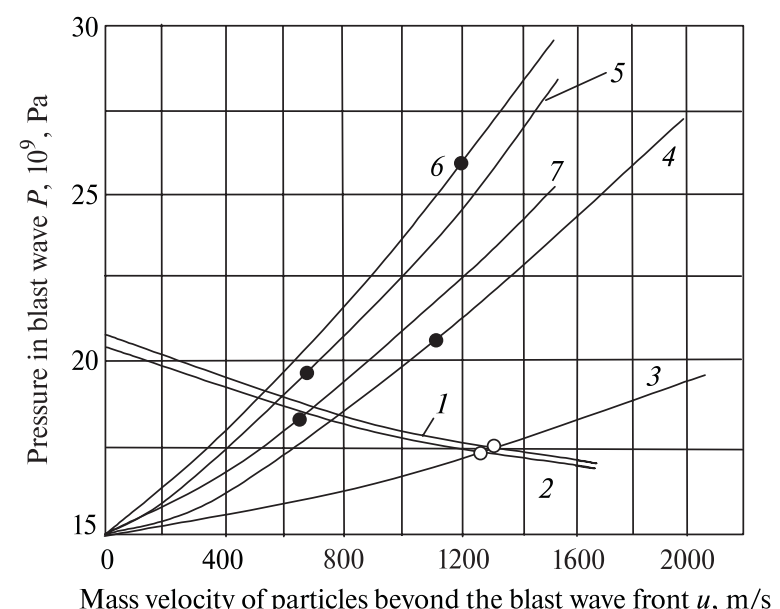

Fig. 3. Impact adiabats of coal rocks, isentropes of detonation products of emulsion explosives

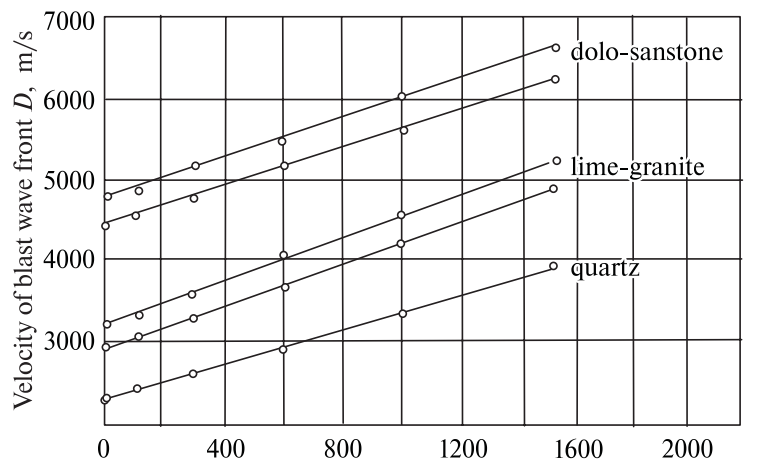

Mass velocity of particles beyond the blast wave front $u, \mathrm{~m} / \mathrm{s}$

\section{Fig. 4. D-u diagrams of the rock states}

In terms of sandstone, we will obtain blast wave heating of about $530 \mathrm{~K}$ at blast wave pressure $p=15 \cdot 10^{9} \mathrm{~Pa}$ (it is taken that $\left.n=4, V_{0}=3.5 \cdot 10^{-4} \mathrm{~m}^{3} / \mathrm{kg}, S=4400 \mathrm{~m} / \mathrm{s}, \mathrm{c}=830 \mathrm{~J} / \mathrm{kg} \times \mathrm{K}\right)$.

Different mechanisms of microparticle break-away have been proposed. One of them is in the fact that the heated surface is instable relative to heaving. Use the following formula to evaluate temperature, at which thermal breaking starts, as follows

$$
T_{s}=\frac{1.5(1-\mu) \sigma}{E \cdot \alpha}
$$

where $T_{s}$ is threshold temperature of the beginning of scaling; $E$ is the Young modulus; $\mu$ is the Poisson ratio; $\alpha$ is the coefficient of thermal linear expansion; $\sigma$ is uniaxial compression strength.

Using expressions $(1,2)$, we obtain the expression to estimate threshold pressure $p_{0}$ in a blast wave; if that pressure is exceeded, surface scaling starts (proposed by A. E. Voitenko)

$$
p_{0}=2.6 S^{2}\left[\frac{(1-\mu) \sigma^{2}}{(n+1) E \cdot \alpha \cdot V_{0}^{2}}\right]^{1 / 3} \text {. }
$$

It should be noted that expression (10) has only estimating accuracy; that estimate shows only the fact that the pressures resulting in thermal breaking are within the range of the pressures developed during detonations of condensed explosives. Estimating character of expression (3) is stipulated by the existence of additional factors which are hard to take into consideration; obviously, those factors reduce considerably the pressure threshold which increase results in the beginning of breaking by thermal elastic pressures. There are several most obvious circumstances of that kind, e.g.:
- blast wave causes rock disintegration; moreover, experiencing its decrease along with the distancing from the explosive charge, disintegration degree is unknown within the nearzone boundaries [22];

- the number of ultradisperse fractions within the breaking, depending on the degree of oversaturation with the defects of rock crystal microstructures [23, 24], reduces the thermal breaking threshold;

- porosity and fissility of the environment causes increased heating beyond the blast wave front [21].

Threshold pressure for sandstone is $p_{0}=8.8 \cdot 10^{9} \mathrm{~Pa}$ (the following values are specified: $s=9.7 \cdot 10^{7} \mathrm{~Pa}, \mu=0.25, \alpha=$ $=0.45 \cdot 10^{-5} \mathrm{~K}^{-1}, E=6.2 \cdot 10^{10} \mathrm{~Pa} ; S=4400 \mathrm{~m} / \mathrm{s} ; p=15 \times$ $\left.\times 10^{9} \mathrm{~Pa}\right)$. Similar values of threshold pressure were obtained for limestone $\left(p_{0}=6.5 \cdot 10^{9} \mathrm{~Pa}\right)$, granite $\left(p_{0}=16 \cdot 10^{9} \mathrm{~Pa}\right)$, and dolomite $\left(p_{0}=21 \cdot 10^{9} \mathrm{~Pa}\right)$. In terms of the analysed coal, pressure is not more than $p_{0}=2.8 \cdot 10^{9} \mathrm{~Pa}$. Calculation values of the threshold pressure in terms of blast wave effect differ insignificantly from the value of critical stresses for analogue rocks in the experiments by M.P. Volarovich in case of pressure with shearing. Fig. 3 and $P$ - $u$ diagrams contain points of the corresponding values of thermoelastic pressures.

During their studies on the mechanism of fine rock sample breaking in terms of uniaxial compression with shearing, M. P. Volarovich and his colleagues (1953-1956) pay attention to the fact that the accumulated elastic energy depend mainly on the plastic properties of rock. Increasing uniaxial pressure results in the growing amount of the accumulated elastic energy - rock breaking takes an explosive form. The paper represents the results of calculations showing the necessity to apply much higher pressures for plastic rocks, which corresponds generally to the tendency highlighted in papers by M. P. Volarovich, N.S. Yenikolopov and others.

The main stages of the breaking process will be as follows:

- detonation of the explosive charge generates a blast wave within the near zone; that wave transforms the rock into plastic state as well as heats, consolidates, and displaces it in the radial direction;

- after the blast wave passing, the unstressed rock transforms into the other state, i. e. displacing along the radius, that state remains the same; the stresses tend to zero, in this context, residual rock temperature exceeds considerably the initial temperature before the explosion load;

- rock breaking results in tensile thermoelastic stresses occurring during its cooling;

- explosions in coal results not only in coal fragmentation to the ultradisperse dust and gas generation but also in the formation of chemically active microparticles whose certain share has potential capability to continue active structure breaking with gas emission [25-27].

If the rock is in plastic state, then no thermoelastic stresses occur in it. Formation of thermal stresses is possible only in terms of rock cooling, when it has already passed into elastic state. In this case, thermoelastic stresses become tensile ones, which is known to reduce significantly the threshold of blast wave pressure resulting in thermal breaking.

Thus, thermoelastic stresses may be the cause of one of the possible (or even the main) mechanism of rock breaking to ultradisperse fraction within the near-explosion zone. That effect is almost impossible to eliminate as there is no explosive whose detonation causes no rock heating. Replacement of explosive or changes in design and method of charge placement in a borehole may be one of the techniques to get rid of that negative effect. For instance, a gap is required between the charge surface and borehole wall filled with air [13] or other inert material with the known impact adiabat.

To evaluate pressure on the borehole walls with the consideration of gap, it is possible to use a scheme similar to the one shown in Fig. 1, i. e. taking into account expansion of the explosion products into the air gap [28]. In this case, surface of the explosion products, expanding with the ultrasound veloc- 
ity, represents the blast wave front moving in the air up to its fall on the borehole wall (unstressing continues to the pressure in the air blast wave). To evaluate parameters of blast wave propagation in the air before its impact on the explosion chamber walls and pressure on the chamber walls, it is possible to use calculation methodology proposed in [28].

Conclusion. Impact adiabats have been determined in terms of the rocks, whose samples were selected at Ukrainian open pits, and bituminous coals (gas and coking). Isentropes of detonation products and impact adiabats for two EPA-class explosives produced at Pavlohrad Chemical Plant were constructed. Impact adiabats are represented in the form of $P-u$ diagrams for graphic representation of the pressure within the explosive-rock interface.

A methodology is proposed to evaluate blast wave parameters within the near-explosion zone of the blasthole or borehole charge. Thermoelastic stresses and critically high concentration of crystalline structure defects may be the causes of rock breaking to ultradisperse fraction within the near-explosion zone.

Alternative mechanism of the transition of microstructures of crystalline rock components in the unstable state was considered as well. For instance, it is possible that rock breaking within the near-explosion zone is stipulated by the effect of some additional physical factors. Explosive nature of the rock sample breaking is not the direct consequence of a uniaxial compression with shearing. The cause is in the oversaturation of the structure with the linear and point defects. Exceedance of the value of critical defect concentration results in the excessive reserves of internal energy with the following spontaneous breaking of chemical bonds.

Impact adiabats of coking coals of three grades and isentrope of the detonation products of emulsion explosive EPA P-3 have been constructed. In terms of the coordinates "pressure - mass velocity of particles", curves of impact adiabats of bituminous coal differ by not more than $4 \%$. Thus, use of certain averaged impact adiabat in the calculations will not cause a crude error.

To reduce a degree of rock fragmentation within the nearexplosion zone, it is recommended to use borehole charges with a gap; in this context, physical effect specified in the 1970s should be taken into consideration. Its essence is in the fact that the pressure of impact compression of maximum amplitude always occurs when a blast wave goes out from the porous material onto the surface of stiff barrier. That pressure is always much higher than the pressure formed in case of normal reflection of the air blast wave from the stiff barrier. Generally, it is necessary to take into account considerable increase in costs for the drill-and-blast operations.

Analysis of the scientific results may be the required condition to develop additional safety measures in the sphere of environmental safety during blasting in terms of both open-pit and underground mining.

The authors express their gratitude to the colleagues of State Enterprise "Research-Industrial Complex "Pavlohrad Chemical Plant" and Scientific and Research Institute of High-Energy Materials for their help in the organization and conducting the research of blast-wave rock treatment.

\section{References.}

1. Efremov, E. I., Petrenko, V.D., \& Pastukhov, A. I. (1990). Prediction of blasting rock fragmentation. Monograph. Kiev: Naukova Dumka. Retrieved from http://irbis.fips.ru:8080/ cgi-bin/irbis64r_out/cgiirbis_64.exe.

2. Krysin, R. S., \& Novinskii, V. V. (2006). Rock blasting models. Monograph. Dnepropetrovsk: Art-Press. Retrieved from http://94.158.152.98/opac/index.php?url=/notices/index/ IdNotice:108849/Source:default\#.

3. Voitenko, A. E. (1990). Thermoelastic stresses behind a shock wave in a solid. Izvestiia vuzov. Gornyi zhurnal, (4), 58-61. 4. Howard, V. (2009). Statement of Evidence: Particulate Emissions and Health (An Bord Plenala, on Proposed Ringaskiddy Waste-to-Energy Facility).
5. Sobolev, V.V., Bilan, N.V., Baskevich, A.S., \& Stefanovich, L. I. (2018). Electrical charges as catalysts of chemical reactions on a solid surface, Naukovyi Visnyk Natsionalnoho Hirnychoho Universytetu, (4), 50-58. https://doi.org/10.29202/ nvngu/2018-4/7.

6. Krasnopolskii, I. A., \& Klimenko, A. A. (2009). Waste generation during blasting of non-metallic minerals and some methods for its regulation, forecasting and reduction. Ekolohiia i pryrodokorystubvannia, 12, 114-121.

7. Efremov, E. I., Nikolenko, E. V., \& Barannik, V. V. (2015). Method for effective blasting of flooded rocks in non-metallic quarries. Geotekhnichna mekhanika, (125), 137-145.

8. Vinogradov, Yu. I., \& Paramonov, G. P. (2007). On the distribution of rock destruction products. Zapiski gornogo instituta, 171, 161-166.

9. Kaplunov, D. R., Voronkova, Yu. A., \& Borodkina, N. N. (2018). Methodological principles of comprehensive assessment of air pollution in a mining region. Izvestiia Tula $G U$. Nauki o zemle, (2), 23-14.

10. Doludarev, V. N. (2014). The impact of shells of cylindrical overhead charges on crack formation in solid media. Suchasni resurso-zberihaiuchi tekhnolohii hirnychoho vyrobnytstva, Kremenchuh: KrNU, 1(13), 57-62.

11. Kurinnoi, V.P. (2018). The theoretical foundations of blasting rock destruction: monograph. Dnepr: Izd-vo Natsionalnyi gornyi universitet (NGU). ISBN 978-617-579-087-8

12. Nifadiev, V.I., Kovalenko, V.A., Raiymkulov, M.A., Komissarov, P. V., \& Basakina, S. S. (2018). Gas-dynamic instability during blasting of a borehole charge dispersed by air gaps as a cause of the initial network of cracks in the rock. Vestnik Kyrgyzsko-Rossiiskogo Slavianskogo Univarsiteta, 18(4), 175-179. 13. Prokopenko, V. S. (2017). Destruction of rocks by borehole charges of explosives in the gopher hole: monograph. Kiev: Ihor Sykorskyi KPI: Politekhnika. ISBN 978-966-622-850-8.

14. Malygin, O.N., Sytenkov, V.N., Rubtsov, S. K., \& Dzhos, V.F. (2002). The main ways to reduce dust and gas emissions during large-scale blast in the Muruntau quarry. Gornaia promyshlennost, 4, 24-27.

15. Petelin, E. A. (2013). On the criterium for rational energy saturation of rocks. Naukovi pratsi DonNTU. Seriia "Hirnychoheolohichna”, 2(19), 19-23.

16. Voitenko, A. E., Sobolev, V.V., Prokudin, A. Z., Chebenko, L. Yu., \& Kirichenko, A. L. (2013). Possible cause of rock crushing in the near explosion zone. In Vysokoenergeticheskiie sistemy, protsessy i ikh modeli, (pp. 247-254). Dnepr: Aktsent PP. ISBN 978-966-2607-70-3.

17. Sobolev, V.V., Taran, Yu. N., \& Gubenko, S. I. (1993). Synthesis of diamond in cast iron. Metallovedenie $i$ Termicheskaya Obrabotka Metallov, 1, 2-6.

18. Sobolev, V.V., Taran, Y.N., \& Gubenko, S. I. (1997) Shock wave use for diamond synthesis. Journal De Physique. IV: JP, 7(3), C3-73-C3-75.

19. Kalinichenko, A.S., Kalinichenko, V.A., Niss, V.S., \& Grigiriev, S. V. (2014). Stability of microstructure of quenched aluminum alloys. Litiio i metallurgiia, 1(74), 93-96.

20. Brovin, V. E., \& Menzhulin, M. G. (2006). Calculation of dissipation energies and parameters of stress waves during blasting of cylindrical explosive charges in rock. Zapiski Gornogo instituta, 167(2), 83-85.

21. Trunin, R. F. (Ed.) (1992). Properties of condensed matter at high pressures and temperatures. Arzamas-16: Vsesoiuznyi NII eksperimentalnoi fiziki.

22. Sobolev, V. V., Kulivar,V. V., Melnikov, D. V., \& Kirichenko, A. L. (2018). Estimation of parameters of rock shock compression during contact dennotation of explosive charge. In Perspektyvy rozvytku budivelnykh tekhnolohii. Dnipro NHU, $12^{\text {th }}$ International scientific and practical conference for young scientists, graduate students and students, (pp. 132-135). Retrieved from http://ir.nmu.org.ua/handle/123456789/152335. 23. Danilenko, V. V. (2010). Blasting: physics, engineering, technology. Moscow: Energoatomizdat. ISBN 978-5-283-00857-8. 
24. Soboliev, V., Bilan, N., \& Samovik, D. (2013). Magnetic stimulation of transformations in coal. In Mining of Mineral Deposits, (pp. 221-225). Leiden: CRC Press/Balkema.

25. Rudakov, D., \& Sobolev, V. (2019). A Mathematical Model of Gas Flow during Coal Outburst Initiation. International Journal of Mining Science and Technology, 791-796. https:// doi.org/10.1016/i.ijmst.2019.02.002.

26. Molchanov, O., Rudakov, D., Sobolev, V., \& Kamchantnyi, O. (2018). Destabilization of the hard coal nanostructure by a weak electric field. E3S Web of Conferences 60. https:// doi.org/10.1051/e3sconf/20186000023.

27. Sobolev, V.V., Rudakov, D.V., Molchanov, O. M., Stefanovych, L. I., \& Kirillov, A. K. (2019). Physical and chemical transformations in gas coal samples influenced by the weak magnetic field. Naukovyi Visnyk Natsionalnoho Hirnychoho Universytetu, (6), 52-58.https://doi.org/10.29202/nvngu/2019-6/8. 28. Surov, V. S. (1997). Calculation of the interaction of an air shock wave with porous material. Vestnik Cheliabinskogo Universyteta, 6.Fizika, 124-134.

\section{Оцінка ударно-хвильових параметрів у ближній зоні вибуху при руйнуванні гірських порід свердловинними зарядами}

\section{В. В. Соболєв ${ }^{1}$, В. В. Кулівар ${ }^{1}$, О. Л. Кириченко ${ }^{2}$, А. В. Курляк ${ }^{2}$ О.О. Балакін ${ }^{2}$}

1 - Національний технічний університет «Дніпровська політехніка», м. Дніпро, Україна, e-mail: velo1947@ukr.net 2 - Державне підприємство «Науково-виробниче об’єднання «Павлоградський хімічний завод», м. Павлоград, Дніпропетровська обл., Україна

Мета. Аналіз експериментальних результатів, опис фізичного механізму подрібнення порід і розробка методики розрахунку ударно-хвильових параметрів у ближній зоні вибуху; дослідження можливої ролі термопружних напруг у руйнуванні породи до ультрадисперсних фракцій у ближній зоні вибуху.

Методика. В експериментах використано метод вимірювання динамічної стисливості кам'яного вугілля, заснований на визначенні швидкості ударних хвиль і масової швидкості частинок речовини за фронтом. Метод відображення використано для побудови ізоентропи продуктів детонації вибухових речовин (ВР) і їх ударної адіабати

Результати. Проведені експериментальні дослідження параметрів динамічної стисливості кам'яного вугілля - швидкості ударної хвилі й масової швидкості частинок речовини за фронтом ударної хвилі. Побудовані ударні адіабати для емульсійних ВР ЕРА Р-3 і кам'яного вугілля. Виконано ряд теоретичних досліджень.

Наукова новизна. Запропоновано методику оцінки ударно-хвильових параметрів у ближній зоні вибуху свердловинного або шпурового заряду. Запропоновано фізичний механізм руйнування порід до ультрадисперсних частинок. Причиною одного з можливих, а може бути й головного механізму руйнування гірської породи у ближній зоні вибуху, можуть бути термопружні напруги. В якості альтернативного (або як додатковий фактор) розглядається механізм, обумовлений переходом мікроструктури кристалічних компонентів породи до стану нестійкості. Причиною є перенасичення мікроструктури породи лінійними й точковими дефектами. Перевищення значення критичної концентрації дефектів призводить до надмірного запасу внутрішньої енергії з подальшим спонтанним руйнуванням хімічних зв'язків. Побудовані ударні адіабати коксівного вугілля трьох марок, ізоентропа та ударна адіабата продуктів детонації емульсійної вибухової речовини ЕРА Р-3. У координатах «тиск - масова швидкість частинок» криві ударних адіабат кам'яного вугілля відрізняються не більше ніж на $4 \%$.
Практична значимість. Аналіз наукових результатів може бути необхідною умовою для розробки додаткових охоронних заходів в області екологічної безпеки навколишнього середовища при проведенні вибухових робіт при відкритому й підземному видобутку корисних копалин.

Ключові слова: вибух, порода, ударна адіабата, ізоентропа продуктів вибуху, термопружні напруги

\section{Оценка ударно-волновых параметров в ближней зоне взрыва при разрушении горных пород скважинными зарядами}

\section{В. В. Соболев ${ }^{1}$, В. В. Куливар ${ }^{1}$, А. Л. Кириченко ${ }^{2}$,} А. В. Курляк ${ }^{2}$, О.А. Балакин ${ }^{2}$

1 - Национальный технический университет «Днепровская политехника», г. Днепр, Украина, e-mail: velo1947@ $\underline{\text { ukr.net }}$

2 - Государственное предприятие «Научно-производственное объединение «Павлоградский химический завод», г. Павлоград, Днепропетровская обл., Украина

Цель. Анализ экспериментальных результатов, описание физического механизма измельчения пород и разработка методики расчёта ударно-волновых параметров в ближней зоне взрыва; исследование возможной роли термоупругих напряжений в разрушении породы до ультрадисперсных фракций в ближней зоне взрыва.

Методика. В экспериментах использован метод измерения динамической сжимаемости каменных углей, основанный на определении скорости ударных волн и массовой скорости частиц вещества за фронтом. Метод отражения использован для построения изоэнтропы продуктов детонации взрывчатых веществ (BВ) и их ударной адиабаты.

Результаты. Проведены экспериментальные исследования параметров динамической сжимаемости каменных углей - скорости ударной волны и массовой скорости частиц вещества за фронтом ударной волны. Построены ударные адиабаты для эмульсионных ВВ ЕРА Р-3 и каменных углей. Выполнен ряд теоретических исследований.

Научная новизна. Предложена методика оценки ударно-волновых параметров в ближней зоне взрыва скважинного или шпурового заряда. Предложен физический механизм разрушения пород до ультрадисперсных частиц. Причиной одного из возможных, а может быть и главного механизма разрушения горной породы в ближней зоне взрыва, могут быть термоупругие напряжения. В качестве альтернативного (либо как дополнительного фактора) рассматривается механизм, обусловленный переходом микроструктуры кристаллических компонентов породы в состояние неустойчивости. Причиной является пересыщение микроструктуры породы линейными и точечными дефектами. Превышение значения критической концентрации дефектов приводит к избыточному запасу внутренней энергии с последующим спонтанным разрушением химических связей. Построены ударные адиабаты коксующихся углей трех марок, изоэнтропа и ударная адиабата продуктов детонации эмульсионного взрывчатого вещества ЕРА Р-3. В координатах «давление -массовая скорость частиц» кривые ударных адиабат каменных углей отличаются не более чем на $4 \%$.

Практическая значимость. Анализ научных результатов может быть необходимым условием для разработки дополнительных охранных мер в области экологической безопасности окружающей среды при проведении взрывных работ при открытой и подземной добыче полезных ископаемых.

Ключевые слова: взрыв, порода, ударная адиабата, изоэнтропа продуктов взрыва, термоупругие напряжения

Recommended for publication by A. M. Royenko, Doctor of Technical Sciences. The manuscript was submitted 11.05.19. 